\title{
EFEKTIVITAS PENYELENGGARAAN PELAYANAN PUBLIK DI WILAYAH KALIMANTAN ${ }^{15}$
}

\author{
Oleh: Said Fahil, S.IP ${ }^{16}$
}

\begin{abstract}
The basic functions of the state are improving well-being of and delivering services to the public. In the context of regional autonomy framework, such

functions are becoming much more essential. Unfortunately, empirical evidences show that public service performance is still far from being satisfying. Using NPM (New Public Management) approach, this paper analyses the policy implementation on enhancing service effectiveness in some district/city government in Kalimantan region. The study designates that there is a couple of service dimension need to be refurbished, particularly procedure / mechanism aspect and institutional aspect.
\end{abstract}

Keywords: pelayanan publik, otonomi daerah, Kalimantan.

\section{Pengantar}

...kewenangan besar dimiliki oleh birokrat, sehingga hampir semua aspek kehidupan masyarakat ditangani birokrasi. Kewenangan yang terlalu besar itu bahkan akhirnya menonjolkan peran birokrasi sebagai pembuat kebijakan ketimbang pelaksana kebijakan, lebih bersifat menguasai dari pada melayani masyarakat (Ramlan Surbakti, Kompas 16 Desember 2005).

Penggalan pendapat guru besar Ilmu Politik Universitas Airlangga tersebut sepertinya masih menjadi stigma terhadap profil aparatur penyelenggara negara (birokrasi) di negara ini. Stigma ini tentunya tidak terlepas dari perjalanan panjang sejarah birokrasi publik di Indonesia bahkan di dunia, dimana keberadaan birokrasi lebih identik sebagai alat politik para birokrat (pengatur kebijakan) ketimbang alat negara yang profesional dan tidak berpihak (pelaksana kebijakan) (Purwanto dan Kumorotomo: 2005).

Stigma negatif terhadap birokrasi bukan tidak disadari oleh pemerintah. Berbagai kebijakan untuk memperbaiki stigma tersebut telah ditempuh, misalnya melalui penggodokan RUU Kebijakan Publik yang mengatur hak masyarakat untuk mengajukan class action kepada

\footnotetext{
15. Tulisan ini merupakan saduran dari hasil penelitian PKP2A III LAN Samarinda Tahun 2005 dengan Judul "Peningkatan Efektivitas Penyelenggaraan Pemerintah Daerah Otonom di Kalimantan”

16. Penulis adalah Staf Peneliti Pada Bidang Kajian Aparatur, Pusat Kajian dan Pendidikan dan Pelatihan Aparatur III (PKP2A III) LAN Samarinda.
} 
birokrasi pemerintah yang dinilai buruk dalam melaksanakan tugas pelayanan, serta tindakan hukum bagi aparat yang diduga terlibat penyelewengan dalam proses pemberian layanan.

Sistem pemerintahan yang belum efektif dan efisien merupakan persoalan yang dihadapi oleh pemerintah, disamping kualitas sumberdaya manusia aparatur yang belum memadai. Disamping itu, kinerja pelayanan juga masih lemah yang diindikasikan oleh banyaknya keluhan masyarakat terhadap prosedur pengurusan yang berbelit-belit, biaya siluman, tidak adanya kepastian waktu, sampai kepada sikap aparat yang tidak menyenangkan dalam memberikan pelayanan. Kondisi ini diperparah oleh transisi perubahan sistem pemerintahan sentralistik yang telah berlangsung $1 / 2$ abad kepada sistem pemerintahan otonom, menyebabkan tidak semua daerah siap dengan perubahan sistem yang sangat drastis ini. Ketidaksiapan ini terwujud dengan praktek kebijakan pemerintah daerah yang latah dan kurang kreatif.

Mengingat kondisi pelayanan yang masih carut marut tersebut, maka tulisan ini mencoba mengevaluasi sejauhmana pemerintah daerah telah melakukan upaya yang benar untuk mendorong tercapainya efektivitas pelayanan kepada masyarakat. Efektivitas penyelenggaraan pemerintahan daerah ini penting sekali tidak saja untuk mengoptimalkan sumber-sumber daya aparatur menekan biaya-biaya yang tidak perlu, namun juga untuk menciptakan sistem pelayanan umum yang benar-benar berkualitas dan memuaskan masyarakat. Tanpa didukung oleh efektivitas yang memadai, tidaklah mungkin pemerintah daerah tidaklah mungkin dapat menunjukkan kinerja yang tinggi di bidang pelayanan publik.

\section{Pelayanan Publik Dalam Konteks Otonomi Daerah}

Kewajiban negara melayani setiap warganegara dan penduduk untuk memenuhi kebutuhan dasarnya dalam kerangka pelayanan publik merupakan amanat UUD 1945. Sebagai penjabaran amanat tersebut di bidang pelayanan sendiri telah dilahirkan banyak peraturan dan/atau keputusan Menteri Pendayagunaan Aparatur Negara, misalnya Keputusan No.63/KEP/M.PAN/7/2003 tentang Pedoman Umum Penyelenggaraan Pelayanan Publik; No.25/KEP/M.PAN/2/2004 tentang Pedoman Umum Penyusunan Indeks Kepuasan Masyarakat Unit Pelayanan Instansi Pemerintah; No.26/KEP/M.PAN/2/2004 tentang Petunjuk Teknis Transparansi dan Akuntabilitas Dalam Penyelenggaraan Pelayanan Publik; Surat Edaran No.15/M.PAN/9/2005 tentang Peningkatan Intensitas Pengawasan Dalam Upaya Perbaikan Pelayanan Publik; dan sebagainya.

Berbagai perubahan kebijakan tersebut pada hakekatnya dimaksudkan untuk mencapai efektivitas dan efisiensi penyelenggaraan pemerintahan daerah yang lebih baik, termasuk di bidang pelayanan publik. Namun fenomena empiris obyektif menunjukkan masih rendahnya efektivitas berorganisasi yang dialami oleh pemerintahan daerah baik propinsi maupun kabupaten/kota di Indonesia. Kecenderungan membengkaknya jumlah perangkat daerah, masih lebih besarnya biaya/belanja rutin dibanding belanja pembangunan, indikasi jumlah personil yang melebihi beban kerja, tuntutan sebagian elit lokal untuk memekarkan wilayah, dan sebagainya, adalah beberapa bukti yang menggambarkan betapa aparat daerah selama ini belum berorientasi pada pemenuhan kebutuhan dan pelayanan masyarakat melalui mekanisme penyelengaraan pemerintahan yang efektif. 
Kondisi ini mengisyaratkan bahwa pembenahan birokrasi pelayanan masih memerlukan perhatian serius dalam segala aspeknya. Model-model kelembagaan pelayanan beserta prosedur mekanisme dan pengaturan pembiayaannya perlu dikaji lebih dalam dan lebih komprehensif lagi, sehingga dapat ditemukan sebuah sistem pelayanan publik yang benar-benar efektif, profesional, serta mampu memenuhi harapan dan kepuasan masyarakat (customer satisfaction).

Dalam konteks peningkatan kualitas pelayanan publik, lahirnya UU No. 32/2004 sebagai hukum positif membawa konsekuensi pada perlunya pengaturan lebih lanjut terhadap pasal-pasal yang ada kedalam peraturan pelaksanaannya. Hal inilah yang perlu disikapi dan diantisipasi sejak dini melalui pengkajian yang cukup matang dan komprehensif, sehingga pemberlakuan kebijakan yang baru di bidang pemerintahan daerah benar-benar dapat meningkatkan efektivitas penyelenggaraan pemerintahan daerah. Efektivitas penyelenggaraan pemerintahan daerah ini penting sekali tidak saja untuk mengoptimalkan sumber-sumber daya aparatur menekan biaya-biaya yang tidak perlu, namun juga untuk menciptakan sistem pelayanan umum yang benar-benar berkualitas dan memuaskan masyarakat. Tanpa didukung oleh efektivitas yang memadai, tidaklah mungkin pemerintah daerah dapat menunjukkan kinerja yang tinggi di bidang pelayanan publik.

Otonomi daerah sendiri merupakan salah satu wujud desentralisasi urusan pemerintahan yang telah sejak lama dilaksanakan di Indonesia. Daerah otonom adalah kesatuan masyarakat hukum yang memiliki batas daerah tertentu yang berwenang mengatur dan mengurus kepentingan masyarakat setempat menurut prakarsa sendiri berdasarkan aspirasi masyarakat dalam ikatan NKRI (Sarundajang, 2001: 146-147).

Konsep otonomi daerah dalam analisisnya selalu disandingkan dengan konsepsi desentralisasi, dua terminologi yang mengandung makna tidak jauh berbeda yaitu menunjuk pada suatu model pemerintahan di daerah. Bhenyamin Hoesein (1993: 14) mengemukakan bahwa desentralisasi mengandung dua pengertian: Pertama, desentralisasi dapat mengandung arti pembentukan daerah otonom dan penyerahan wewenang tertentu kepadanya oleh pemerintah pusat, Kedua desentralisasi dapat pula diartikan penyerahaan wewenang tertentu kepada daerah otonom yang telah dibentuk oleh pemerintah pusat. Dengan demikian desentralisasi dapat pula dipahami sebagai suatu proses penyerahan wewenang kepada daerah baik dibentuk dulu baru diserahkan atau menyerahkan kepada daerah otonom yang sudah ada, agar dengan kewenangan tersebut daerah dapat menjalankan fungsi dan perannya secara mandiri atau secara otonomi. Dengan demikian otonomi daerah adalah output atau tujuan dari proses desentralisasi.

Penerapan desentralisasi akan dapat mendorong terhadap pemberdayaan (empowering) dan penguatan (strengthening) daerah baik Pemerintah Daerah maupun masyarakat daerah (UNDP, 1996). Penerapan desentralisasi juga akan memberikan keuntungan-keuntungan sebagai berikut:

- Penerapan desentralisasi memungkinkan pemerintahan dalam hal ini pemerintah daerah akan lebih memahami kebutuhan dan keinginan daerah/masyarakat daerah (better knowledge of local demands); 
- Memungkinkan pemerintah lebih mampu merespon atau menjawab berbagai tantangan dan tuntutan dari masyarakat (ability to respond to local cost variations);

- Meningkatkan partisipasi masyarakat dalam menentukan jalannya pemerintahan (increased scope for community participation); dan

- Mendekatkan jarak antara masyarakat dan pemerintah sehingga masyarakat merasakan manfaat yang didapat dari biaya yang dikeluarkannya (closer correspondence between costs and benefits).

Namun demikian penerapan desentralisasi di negara-negara berkembang perlu dipersiapkan dan dikelola dengan baik apabila tidak dipersiapkan dan dikelola dengan baik tidak tertutup kemungkinan akan menimbulkan permasalahan-permasalahan yang jauh lebih kompleks dari sebelumnya. Salah satu dampak dari penerapan desentralisasi yang kurang baik justru dapat menambah semakin lebarnya kesenjangan dan ketidakmerataan antara masyarakat miskin dengan pelayanan publik yang ada. Beberapa temuan penelitian menunjukkan realitas tersebut justru banyak ditemukan di negara-negara berkembang ketika menerapkan kebijakan otonomi daerahnya. Permasalahan-permasalahan tersebut timbul baik di level pusat dan daerah karena keterbatasan sumber daya yang dimilikinya.

Untuk mencegah terjadinya permasalahan tersebut dalam penerapan desentralisasi terlebih dahulu perlu ditata suatu kondisi yang kondusif, dimana perwujudannya dilakukan secara bertahap dan terpadu. Minimal terdapat 5 kondisi penting yang dibutuhkan dalam menerapkan desentralisasi menurut World Bank (2000: 25) adalah sebagai berikut:

1. The decentralization framework must link, at the margin, local financing and fiscal authority to the service provision responsibilities and functions of the local government so that local politicians can bear the costs of their decisions and deliver on their promises;

2. The local community must be informed about the costs services and services delivery options involved and the resource envelope and its sources - so that the decisions they make are meaningful.

3. There must be a mechanism by which the community can express its preferences in a way that is binding on the politicians - so that there is a credible incentives for people to participate;

4. There must be a system of accountability that relies on public and transparent information which enables the community to effectively monitor the performance of the local government and react appropriately to that performance so that politicians and local officials have an incentive to be responsive

5. The instruments of decentralization - the legal and institution framework, the structure of service delivery responsibilities and the intergovernmental fiscal system - are designed to support the political objectives.

Dalam konteks penyelenggaraan otonomi daerah, yang menjadi sasaran pembangunan adalah masyarakat bangsa. Salah satu instrumen pembangunan yang merupakan hak prerogatif pemerintah terhadap masyarakat adalah layanan publik. Masyarakat berhak atas berbagai layanan yang harus diberikan oleh pemerintah, karena pada dasarnya pemerintah dibentuk untuk melayani masyarakat. Atau dengan kata lain, pemerintah berkewajiban penuh untuk memberikan layanan kepada masyarakat. Kesadaran akan hak layanan yang harus diterima oleh masyarakat dan kewajiban memberikan layanan yang harus dilaksanakan oleh pemerintah merupakan dua hal penting untuk mewujudkan kinerja pelayanan umum yang baik. 
Saat ini, kesadaran masyarakat akan hak layanan yang harus diterimanya mulai muncul sebagai suatu fenomena riil, seiring dengan merebaknya iklim demokratisasi dan keterbukaan. Munculnya fenomena ini menunjukkan terjadinya pergeseran nilai-nilai tradisional dalam masyarakat dari sikap yang pasif dan selalu "akomodatif" yang terlalu menjunjung budaya "paternalisme”, menjadi sikap aktif dan kritis yang mencerminkan sikap demokratis dan partisipatif.

Proses perubahan dan pergeseran tatanan nilai-nilai tersebut merupakan suatu proses yang biasa terjadi dalam suatu bangsa yang sedang membangun. Namun demikian perubahan tersebut seyogyanya diarahkan dan diatur agar dapat mendukung perwujudan masyarakat madani (civil society) yang demokratis bukan masyarakat taklid namun anarkis. Salah satu sikap kritis masyarakat yang mulai tumbuh saat ini, sebagaimana disebutkan, antara lain adalah tuntutan akan kualitas pelayanan yang diberikan pemerintah. Namun di sisi lain juga, masyarakat semakin sadar akan kewajibannya, seperti membayar pajak dan retribusi.

Sementara itu, berkaitan dengan hak-hak layanan yang melekat pada publik, Henry (dalam Ibrahim, 1997:18) mendefinisikan public service sebagai suatu pengertian yang ditujukan kepada suatu pelayanan terhadap kebutuhan yang bersifat umum dari masyarakat dan karena itu dapat dituntut agar dilaksanakan. Berbeda dengan public utilities yang diartikan sebagai pelayanan atas komoditi dan jasa dengan mempergunakan sarana milik umum, yang dapat dilakukan oleh orang/badan keperdataan namun harus dengan pelayanan dengan tanpa diskriminasi. Sementara itu, public interest law (pro bono publico) menurut Henry merupakan bentuk karya pelayanan yang dilakukan karena belas kasihan demi kemanfaatan / kebaikan umum.

Selanjutnya, upaya peningkatan kualitas dan jangkauan layanan tidak lain dari bagaimana mengelola layanan umum dengan baik. Dalam hal ini service management merupakan instrumen pengelolaan layanan yang harus dipahami oleh pemerintah. Atas dasar pengertian dan kriteria sebagaimana disebutkan tersebut, maka pelayanan yang secara umum diharapkan harus mempunyai kriteria: 1) kemudahan dalam pengurusan kepentingan; 2) mendapatkan pelayanan wajar; 3) mendapatkan perlakuan yang sama tanpa pilih kasih; serta 4) mendapatkan perlakuan yang jujur dan terus terang. Apabila pelayanan yang diberikan pemerintah tersebut memenuhi kriteria-kriteria tersebut, maka dia akan memberikan kepuasan kepada masyarakat, yang pada akhirnya akan berdampak positif berupa: masyarakat menghargai pemerintah, masyarakat patuh terhadap aturan-aturan layanan, masyarakat bangga terhadap pemerintah, ada kegairahan usaha dalam masyarakat, serta ada peningkatan dan pengembangan dalam masyarakat.

\section{Upaya Peningkatan Kualitas Pelayanan Publik}

Upaya peningkatan kualitas pelayanan akan ditentukan oleh sejauh mana institusi pelayanan yang bersangkutan mampu memberikan pelayanan yang sebaik-baiknya. Untuk merealisasikan pemberian pelayanan sebaik-baiknya dengan kualitas yang diharapkan tidak mudah, tetapi perlu dilakukan langkah-langkah strategis. DeVyre dalam buku Good Service is Good Business (1997) mengemukakan tujuh strategi menuju keberhasilan pemberian pelayanan. Ketujuh strategi tersebut adalah: 
- Self esteem: dimaksudkan sebagai upaya memberikan nilai pada diri sendiri secara internal, termasuk di dalamnya memberikan perhatian terhadap pegawai dan bersikap keteladanan bagi mereka.

- Exceed expectation: yaitu memenuhi harapan-harapan dan berusaha melebihi apa yang telah dijanjikan lebih rendah kenyataannya dari janji tersebut.

- Recover: didalamnya termasuk tanggapan atas keluhan pelanggan dan mencari tahu apa yang dipikirkan konsumen tentang perusahaan.

- Vision: di dalamnya termasuk pemikiran tentang rencana yang matang mengenai pelayanan jangka panjang, termasuk memperhitungkan penilaian pelanggan sehingga terus menjadi perhatian perusahaan

- Improve: yakni berusaha untuk melakukan peningkatan secara berencana dan terus menerus sehingga mempunyai kemampuan untuk bersaing dan memenangkan persaingan.

- Care: menaruh perhatian yang cukup terhadap pelanggan sehingga mereka merasa dihargai dan betul-betul diperhatikan, sekalipun mungkin sebagian diantaranya hanya basa-basi.

- Empower: yakni memberdayakan pegawai dengan memberikan latihan, menanamkan rasa tanggung jawab, percaya kepada kemampuan diri serta menggugah untuk memberikan respon.

Dari pengalaman yang terjadi di lapangan, metode pemberian pelayanan yang baik sebenarnya ditentukan oleh sejauh mana ketepatan pelayanan yang diberikan dengan keadaan nyata pada lingkungan masyarakat yang diberi pelayanan. Lingkungan yang dimaksud menyangkut baik lingkungan fisik maupun lingkungan sosial yang mempengaruhi sikap dan perilaku masyarakat. Hal tersebut dapat dikatakan sebagai suatu pendekatan yang bersifat kontekstual, karena pelayanan yang baik pada suatu masyarakat belum tentu diterima bila mana diberikan pada lingkungan masyarakat lainnya.

Beranjak dari pendekatan kontekstual, menurut Saefullah (1999:13) metode yang kiranya dapat menghasilkan pelayanan yang baik, dilakukan melalui langkah-langkah sebagai berikut:

1. Melakukan pengamatan secara mendalam tentang lingkungan masyarakat yang akan diberikan pelayanan.

2. Menganalisa data dan informasi dari lapangan dengan seksama untuk memahami bagaimana keadaan masyarakat yang menjadi sasaran.

3. Merencanakan langkah-langkah secara sistematis, termasuk menentukan tenaga dan sarana yang dianggap tepat.

4. Melaksanakan pemberian pelayanan dengan memperhatikan:

- Menghilangkan jarak antara aparat pemberi pelayanan dengan individu yang diberi pelayanan.

- Menghindarkan perilaku yang membuat segan apalagi takut bagi pihak yang diberi pelayanan.

- Mengintegrasikan diri dengan suasana kehidupan masyarakat yang dilayani

- Menghormati perbedaan-perbedaan yang ada dilapangan, baik secara kelompok maupun individual

- Menghargai individu yang diberi pelayanan dengan prinsip Human relations.

- Memberikan kesempatan bertanya atau menyampaikan keluhan dari pihak yang diberi pelayanan, bahkan diupayakan agar mereka berani memberikan penilaian terhadap pihak yang memberi pelayanan 
5. Melakukan evaluasi terhadap pelaksanaan pelayanan untuk perencanaan dan pemberian pelayanan pada masa yang akan datang.

Dalam upaya merubah orientasi pelayanan kepada kepuasan masyarakat (customer satisfaction) dalam penyelenggaraan pelayanan publik, maka Kontrak Pelayanan (KP) yang dilembagakan adalah salah satu upaya yang bisa dikembangkan guna menumbuhkan budaya dan orientasi pelayanan serta lebih menjamin kepastian dalam penyelenggaraan pelayanan kepada masyarakat (Kusumari, 2005).

KP adalah suatu pendekatan dalam penyelenggaraan pelayanan publik yang menempatkan pengguna layanan sebagai pusat perhatian. Artinya, kebutuhan dan kepentingan pengguna layanan harus menjadi pertimbangan utama dalam keseluruhan proses penyelenggaraan pelayanan publik. Untuk mencapai maksud tersebut, kontrak pelayanan mendorong penyedia layanan bersama-sama dengan pengguna layanan dan pihak-pihak yang berkepentingan menyepakati jenis, prosedur, waktu, biaya, serta cara pelayanan. Kesepakatan tersebut harus mempertimbangkan keseimbangan hak dan kewajiban antara penyedia layanan, pengguna layanan, serta stakeholders. Kesepakatan inilah yang nantinya menjadi dasar praktik penyelenggaraan pelayanan publik.

KP ini diperlukan untuk: 1) Memberikan kepastian pelayanan (jenis, waktu, biaya dan prosedur); 2) Memberikan informasi antara hak dan kewajiban pengguna layanan, warga, dan stakeholders; 3) Mempermudah fungsi control; 4) Mempermudah manajemen pelayanan dan memperbaiki kinerja penyelenggara pelayanan; 5). Mengidentifikasi kebutuhan, harapan dan aspirasi pengguna layanan. Tujuan pelembagaan KP dalam penyelenggaraan pelayanan publik adalah membuat pelayanan publik menjadi lebih responsif, yaitu sesuai antara pelayanan yang disediakan dengan kebutuhan masyarakat, dan transparan dari segi waktu, biaya, dan cara pelayanan, serta akuntabel. Selain itu, dengan adanya kontrak pelayanan, pengguna pelayanan juga dapat mengakses informasi pelayanan dan melakukan kontrol terhadap penyelenggaraan pelayanan serta menghargai martabat dan kedudukan pengguna layanan sebagai warga yang berdaulat. Bagi penyedia layanan sendiri, kontrak pelayanan bermanfaat untuk memudahkan evaluasi terhadap kinerja pelayanan. Disamping itu, beberapa keuntungan melakukan pelembagaan kontrak pelayanan antara lain, adalah:

- Mendorong perubahan struktur birokrasi seperti perubahan prosedur pelayanan dan posisi pengguna jasa.

- Pengguna jasa pelayanan, civil society organization (CSO), dan media massa dapat melakukan peran kontrol dalam penyelenggaraan pelayanan publik karena adanya mekanisme komplain apabila pelayanan tidak sesuai dengan standar.

- $\quad$ Mendorong perubahan mindset dan perilaku aparat birokrasi (penyelenggara pelayanan) menjadi lebih berorientasi pada kepentingan publik.

- Fisibilitas politik tinggi karena melibatkan partisipasi dan aspirasi masyarakat, LSM, dan DPRD dalam menyusun prosedur, peraturan, dan standar kinerja pelayanan.

- Melindungi masyarakat dari perilaku birokrasi yang sewenangwenang maupun sikap arogansi aparat birokrasi terhadap pengguna jasa.

- Adanya transparansi waktu, biaya, dan prosedur pelayanan.

- Adanya kejelasan SDM yang menangani suatu pelayanan dan kualitas SDM yang lebih baik.

- Menciptakan budaya dan etika pelayanan baru yang menempatkan pengguna jasa sebagai subjek pelayanan. 
Kontrak Pelayanan sebagai salah satu pendekatan dalam manajemen penyelenggaraan pelayanan walaupun belum menjadi ketetapan dalam peraturan penyelenggaraan pelayanan secara nasional, namun beberapa daerah sudah mulai mencoba mengadopsi prinsip tersebut. Pemerintah Kota Balikpapan didalam penyelenggaraan pelayanan administrasi kependudukan selain memberikan pilihan waktu penyelesaian pelayanan dengan konsekuensi biaya yang lebih besar juga memberlakukan mekanisme denda kepada penyelengara pelayanan jika tidak bisa memenuhi target waktu pelayanan yang dipilih oleh pengguna layanan.

\section{Arah Implementasi Kebijakan Peningkatan Kualitas Pelayanan Publik}

Secara umum dapat diamati bahwa penyelenggaraan pelayanan umum oleh instansi pemerintah dewasa ini belum menunjukkan kinerja dan harapan seperti yang diharapkan. Hal ini dapat dilihat dari banyaknya prosedur dan mekanisme pelayanan yang belum efisien dan cenderung berbelit-belit, tidak transparan, kurang informatif, kurang akomodatif, kurang konsisten sehingga tidak menjamin kepastian (hukum, waktu dan biaya), serta masih dijumpai adanya praktek pungutan liar dari oknum yang meminta imbalan yang tidak semestinya, dan banyak memberikan peluang terjadinya KKN. Dilain pihak masyarakat sebagai unsur utama yang dilayani belum juga memberikan kontrol yang efektif sebagai unsur pendorong dalam upaya peningkatan kualitas pelayanan.

Masih rendahnya kinerja pelayanan publik juga dipengaruhi oleh budaya paternalisme dan sistem pembagian kekuasaan yang cenderung berpusat pada pimpinan. Selain itu, sistem insentif yang dikembangkan dalam birokrasi publik belum mampu mendorong pelaku birokrasi untuk memperbaiki kinerjanya. Penghargaan terhadap pejabat birokrasi yang mampu menujukkan prestasi kerja dan memberi pelayanan yang baik belum banyak dilakukan. Dari perspektif pendayagunaan aparatur negara, berbagai kondisi negatif dan rendahnya kinerja pelayanan publik disebabkan oleh faktor-faktor antara lain sebagai berikut:

1. Faktor Kelembagaan, meliputi:

- Struktur organisasi belum mendukung dan mencerminkan fungsi pelayanan karena pada umumnya struktur organisasi pemerintah masih sangat hirarkis (tidak flat/datar).

- Masih terjadi tumpang tindih tugas/kewenangan antar sektor maupun antar level pemerintah.

2. Faktor Sumber Daya Manusia Aparatur, meliputi:

- Kompetensi SDM yang duduk dalam jabatan belum memadai.

- Program pembinaan belum terencana dengan baik, bertahap dan berkelanjutan.

- Pengembangan jabatan fungsional di bidang pelayanan publik masih sangat terbatas.

- Tingkat kesejahteraan pegawai belum memadai.

- Belum tumbuh budaya kerja aparatur yang kondusif.

3. Faktor Ketatalaksanaan, meliputi:

- Belum ditetapkan berbagai standar pelayanan yang baku.

- Mekanisme dan prosedur pelayanan belum efisien.

- Waktu penyelesaian dan biaya tidak transparan.

- Sarana dan prasarana kerja kurang memadai.

- Kurangnya informasi pelayanan.

4. Faktor Pengawasan dan Akuntabilitas, meliputi:

- Temuan hasil pengawasan mengenai berbagai kelemahan pada unit pelayanan tidak/kurang ditindak lanjuti. 
- Kurangnya dikembangkan sistem reward dan punishment.

- Kurangnya respon/perhatian terhadap kritikan, pengaduan dan saran masyarakat.

- LAKIP/AKIP belum berfungsi secara efektif dalam rangka peningkatan kinerja, terutama di bidang pelayanan.

Dalam rangka mengatasi permasalahan dan kendala tersebut diatas, Kantor Menpan telah menempuh kebijakan peningkatan kualitas pelayanan publik, yang meliputi dimensi-dimensi sebagai berikut:

1. Deregulasi dan debirokratisasi di bidang pelayanan publik, dengan mengkaji dan menyempurnakan berbagai peraturan perundang-undangan yang melandasi penyelenggaraan pelayanan di berbagai instansi pemerintah untuk lebih memebrikan kemudahan kepada masyarakat.

2. Peningkatan profesionalisme pejabat pelayanan publik. Langkah-langkah yang perlu dilakukan dalam upaya meningkatkan profesionalisme petugas pemberi pelayanan.

3. Korporatisasi Unit Pelayanan Publik. Salah satu kebijakan pemerintah dalam upaya peningkatan mutu pelayanan masyarakat, antara lain melalui kebijakan otonomi manajemen (korporatisasi), yaitu pemberian kewenangan secara eksplisit dan jelas kepada unit/satuan kerja tertentu dari instansi pemerintah untuk menyelenggarakan manajemen operasional pelayanan secara mandiri dan otonom.

4. Pengembangan dan pemanfaatan E-Government bagi instansi pelayanan publik. Dalam rangka peningkatan pelayanan publik, maka pengembangan penyelenggaraan $E$ Government atau Government On-line pada seluruh organisasi pemerintah, baik di Pusat maupun Daerah terutama kepada instansi yang memberikan pelayanan kepada masyarakat. Melakukan koordinasi keterpaduan sistem penyelenggaraan E-Government melalui jaringan informasi on-line antar instansi pemerintah baik pusat maupun daerah untuk mengakses seluruh data dan informasi terutama yang berkaitan dengan pelayanan publik dalam aspek transparansi, akuntabilitas dan partisipasi masyarakat. Selanjutnya perlu dikembangkan untuk memberikan pelayanan interaktif, sehingga melalui internet masyarakat dapat mengakses berbagai penyelenggaraan pelayanan publik.

5. Peningkatan partisipasi masyarakat dalam pelayanan publik. Dalam rangka mewujudkan transparansi dalam pelaksanaan pelayanan publik oleh aparatur, akan dikembangkan suatu konsespsi dengan membangun ketertiban/partisipasi masyarakat dalam penyelenggaraan fungsi-fungsi pelayanan publik untuk membangun kreativitas dan partisipasi masyarakat dalam pembangunan di samping masyarakat dapat berpartisipasi penuh dan melakukan pengawasan sosial (social control).

6. Pemberian penghargaan dan sanksi kepada unit pelayanan masyarakat. Dalam rangka memberikan stimulasi/rangsangan atau dorongan/motivasi dalam memberikan pelayanan yang baik, maka perlu adanya pemberian penghargaan dan sanksi kepada unit pelayanan.

Semenjak tahun 2002 sendiri, berbagai kebijakan makro strategis dalam rangka peningkatan kualitas pelayanan publik, telah pula dilakukan, diantaranya:

1. Penyusunan RUU tentang Pelayanan Publik (sampai sekarang belum final).

2. Penyusunan Konsep Indeks Kepuasan Pelanggan.

3. Penilaian dan Pemberian Penghargaan Kepala Unit Pelayanan Percontohan.

4. Akta Layanan Publik

5. Sosialisasi dan optimalisasi pemanfaatan teknologi informasi dalam rangka E-government untuk menunjang kualitas pelayanan publik aparatur pemerintah

Namun sepertinya kebijakan makro strategis tersebut belum efektif dalam tataran implementasi, baik ditingkat finalisasi kebijakan (undang-undang) maupun sampai pada petunjuk pelaksanaan yang jelas dan tegas secara nasional. Disamping itu, kondisi peraturan perundang-undangan di bidang pelayanan umum yang masih terfragmentasi dan belum cukup 
mengatur aspek-aspek pelayanan umum yang diperlukan, maka potensi terjadinya penyimpangan terhadap kewajiban pelayanan umum relatif cukup besar. Oleh karena itu, untuk menjamin tercapainya pelayanan umum yang memuaskan masyarakat, diperlukan sebuah UU yang secara khusus mengatur tentang pelayanan umum dan yang memiliki sanksisanksi, sehingga memiliki daya paksa terhadap pemenuhan suatu standar tertentu dalam pelayanan umum. Adapun tujuan penyusunan UU tentang Pelayanan Umum adalah:

1. Terciptanyana batasan umum yang jelas tentang hak dan kewajiban seluruh pihak yang terkait dengan penyelenggaraan pelayanan umum;

2. Terciptanya batasan umum yang jelas mengenai tanggungjawab, kewajiban, dan kewenangan penyelenggara pelayanan umum;

3. Terciptanya sistem penyelenggaraan pelayanan umum yang layak, sesuai dengan asasasas umum pemerintahan yang baik dan bersih;

4. Terselenggaranya pemenuhan kebutuhan dasar dan hak-hak sipil masyarakat di dalam pemanfaatan pelayanan umum.

Hughes (1994) berpendapatan bahwa manajemen pelayanan publik harus dikembalikan kepada posisinya yang bersifat administratif dan apolitis ${ }^{17}$. Salah satu formula untuk mengembalikan fungsi pelayanan yaitu dengan penerapan konsep New Public Management (NPM). NPM sebenarnya merupakan model manajemen pelayanan publik dengan ciri yang lebih mengarah pada inside the organisation yaitu: 1) memfokuskan aktivitasnya hanya pada kegiatan manajemen, tidak pada aktivitas kebijakan; 2) mencoba melihat manajemen pelayanan publik pada segi kinerja (performance appraisal) dan efisiensi, tidak dari segi politis; 3) pemecahan manajemen pelayanan publik menjadi badan-badan kecil dan sederhana yang berkaitan langsung dengan kepentingan dasar pengguna jasa (user-pay bases); 4) menggunakan landasan pasar (quasi-markets) sebagai daya dorong bagi terciptanya kompetisi; 5) pemangkasan ekonomi biaya tinggi sehingga ongkos untuk memperoleh pelayanan menjadi lebih murah ${ }^{18}$. NPM, menurut Rhodes (1994: 2), juga ditandai dengan gaya insentif moneter, dan kebebasan pengelolaan. Cara pengelolaan seperti ini diharapkan sesuai dengan semangat desentralisasi di Indonesia.

Ferlie (1997: 10-15) mengemukakan setidaknya ada 4 (empat) model NPM. Keempat model tersebut yaitu;

Model 1: The Efficiency Drive. Model ini dapat dilihat kemunculannya pada pertengahan tahun 1980-an. Model ini menghendaki sektor publik dikelola secara bisnis, dengan jargon efisiensi. Penasehat-penasehat pemerintatah berasal dari sektor privat. Badanbadan penasehat memegang peran penting dalam pengembangan sektor publik. Pembentukan badan-badan penasehat di sektor publik yang berasal dari sektor privat dilandasi asumsi bahwa sektor publik selalu bloated, wasteful, "overbureaucratic, dan underperforming, dan akan menjadi lebih baik bila privat dilibatkan.

17 Persoalan dikotomi politik administrasi sebenarnya merupakan persoalan klasik yang pada saat ini sudah tidak dipersoalkan lagi. Karena itu penempatan birokrasi pada urusan non politis bukanlah merupakan tuntutan baru. Tetapi hanya sekedar memberikan abstraksi yang jelas mengenai posisi birokrasi. Untuk lebih jelasnya lihat Owen E. Hughes., 1994, Public Management and Administration, St. Martin's Press, New York.

18 Konsep pemangkasan biaya berbeda dengan konsep penekanan biaya (irit). Konsep pemangkasan biaya berarti pemotongan biaya yang seharusnya tidak perlu. Konsep pemangkasan biaya tidak mempersoalkan besar kecilnya biaya. Kalau kegiatan yang dilakukan memang memerlukan biaya besar, biaya besar tidak menjadi persoalan. Begitu juga sebaliknya. 
Model 2: Downsizing and Decentralization. Model ini sebenarnya merupakan perbaikan model pertama. This has resulted in some very general organizational development including: organizational unbundling (pengurangan berkas) and downsizing; a search for greater organizational flexibility; a move from a high degree of standardization; increased decentralization of strategic and budgetary responsibility; increased contracting-out; and a split between a small strategic core and a large operational periphery.

Model 3: In Search of Excellence. Model ini lebih menekankan pada pentingnya kultur organisasi (organizational culture). Model ini menolak dengan keras pendekatan rasionalistik NPM model 1 dan instead highlights the role of values, culture, rites, and symbols in shaping how people actually behave at work. Ada interes yang kuat dalam hal bagaimana organisasi mengatur (manage) perubahan dan inovasi melalui perubahan kultur.

Model 4: Public Service Orientation. Model ini mencoba menggabungkan ide-ide manajemen sektor publik dan privat, dengan re-energizing public sector managers by outlining a distinct service mission. Memperjelas tujuan dan menjamin bahwa pengguna lebih diperhatikan dalam memberikan pelayanan, merupakan ciri khas model ini.

Secara umum, kondisi empiris penyelenggaraan pelayanan masih sebatas pemenuhan fungsi administratif penyelenggara pemerintahan, termasuk di daerah. Walaupun demikian, keinginan untuk merubah orientasi pelayanan kepada pemenuhan kebutuhan dan kepuasan masyarakat sudah mulai terbangun. Sebagai contoh, pemerintah Kota Balikpapan dalam penyelengaraan manajemen kependudukan sudah mengakomodir beberapa prinsip NPM. Diantaranya adalah, menyediakan pilihan-pilihan jenis layanan kepada masyarakat. Dimana masyarakat dapat memilih jenis layanan dalam pengurusan administrasi kependudukan sesuai dengan kebutuhan. Bagi masyarakat yang menginginkan jenis layanan dengan waktu penyelesaian layanan lebih cepat dari waktu standar yaitu 12 hari kerja. Adapun pilihanpilihannya yaitu, 3 (tiga) jam, 1 (satu) hari dan 3 (tiga) hari. Makin singkat waktu layanan yang dipilih maka makin besar jumlah biaya yang harus dikeluarkan.

\section{Potret Pelayanan Publik di Daerah (Kalimantan)}

Sebuah survei yang dilakukan secara nasional mengenai Governance dan Desentralisasi pada tahun 2002 dengan cakupan 150 kabupaten/kota di Indonesia menemukan tiga masalah besar dalam pelayanan publik yaitu, besarnya diskriminasi pelayanan, tidak adanya kepastian pelayanan dan rendahnya tingkat kepuasan masyarakat terhadap pelayanan publik (Dwiyanto: 2003).

Diskriminasi dalam pemberian pelayanan sering muncul karena persepsi mengenai hak dan kewajiban antara penyedia layanan dan pengguna layanan belum mencapai titik temu. Disamping itu budaya birokrasi di Indonesia yang mengadopsi budaya Jawa yang hierarkhis, tertutup, sentralistis, dan mempunyai nilai untuk menempatkan pimpinan sebagai pihak yang harus dihormati (Niels: 1985). Selain tidak tegasnya mekanisme sanksi bagi aparat pemberi layanan yang tidak baik dan menyimpang, tidak adanya sistem insentif yang secara efektif 
mampu mendorong para pejabat birokrasi untuk bekerja secara efisien dan professional, turut memberi kotribusi terhadap buruknya mutu pelayanan publik di Indonesia.

Hasil penelitian PKP2A III LAN Samarinda, menunjukkan bahwa, pelayanan di wilayah Kalimantan masih menghadapi banyak kendala, baik kelembagaan, ketatalaksanaan maupun SDM, namun demikian komitmen dan upaya untuk mengatasi kendala tadi sekaligus memperbaiki kualitas pelayanan sudah mulai terbangun. Dengan kata lain, secara umum pelayanan kepada masyarakat belum berjalan dengan baik, khususnya di daerah pemekaran seperti Barito Selatan dan Sambas (catatan: Kabupaten Sambas sesungguhnya merupakan kabupaten induk yang dimekarkan menjadi 3 daerah otonom, namun memindahkan ibukota dari Kecamatan Singkawang ke Kecamatan Sambas; Singkawang sendiri sekarang menjadi Kota Otonom). Sementara di Kota Balikpapan, pelayanan publik (khususnya pelayanan kependudukan) sudah sangat maju dan bahkan menjadi percontohan secara nasional. Dengan demikian dapatlah diketahui bahwa kondisi antar daerah sangat beragam, dan kinerja pelayanannya-pun cukup bervariasi.

Di Kabupaten Sambas, upaya peningkatan efektivitas pelayanan telah ditempuh dengan membentuk Badan Kerjasama dan Investasi (BKI), yang antara lain bertugas memberikan lebih dari 25 jenis pelayanan perijinan. Selain itu, Bupati telah mengeluarkan berbagai perintah penting kepada instansi terkait, antara lain untuk mengkaji standar pelayanan perizinan, melakukan evaluasi terhadap implementasi sistem dan prosedur pelayanan, menempatkan papan informasi tentang skema alur pelayanan lengkap dengan persyaratannya, dan sebagainya. Sayangnya, dalam praktek masih lebih berfungsi sebagai information center dari pada sebagai front office untuk semua jenis layanan yang dilakukan. Artinya, pelayanan teknis masih dilakukan oleh dinas/kantor yang bersangkutan. Dengan demikian, yang terjadi justru inefisiensi kelembagaan dan sumber daya lainnya. selain itu, berbagai instruksi Bupati nampaknya juga belum dapat terlaksana dengan baik, sehingga belum mampu mendongkrakk mutu dan efektivitas pelayanan publik di daerah.

Serupa dengan Kabupaten Sambas, langkah peningkatan efektivitas pelayanan di Kabupaten Banjar ditempuh melalui pembentukan Tim Koordinasi Perizinan Investasi yang diberi tugas untuk membantu Bupati merumuskan kebijakan di bidang perizinan investasi yang bersifat strategis. Di Kabupaten Banjar juga telah dikeluarkan berbagai SK Bupati yang mengatur masalah prosedur dan standar pelayanan, serta SK tentang pelimpahan sebagian kewenangan kepada Camat untuk menyelenggarakan beberapa jenis layanan tertentu. Namun dalam prakteknya juga masih ditemui berbagai kendala, salah satunya belum berfungsinya Tim tadi secara optimal, karena lebih merupakan pusat informasi dan koordinasi bagi kegiatan pengurusan perizinan yang berhubungan dengan investasi, sementara sebagian besar pelayanan perijinan secara teknis masih dilakukan oleh unit-unit teknis. Ide untuk mendirikan unit pelayan terpadu terbentur pada alasan pembiayaan dan minimnya dukungan/kerelaan dari unit-unit pelayanan teknis yang selama ini melakukan fungsi pelayanan. Selain itu, prosedur dan mekanisme yang ada sekarang ini dirasakan kurang efektif, hal ini dapat dilihat dari masih banyak prosedur pelayanan yang tidak dapat diimplementasikan secara konsisten, terutama dari aspek waktu penyelesaian jenis pelayanan. 
Sementara itu di Kabupaten Barito Selatan, penyelenggaraan pelayanan pendaftaran penduduk dilakukan oleh Kantor Kependudukan dan Catatan Sipil. Sistem pelayanan masih dilakukan secara manual, pemakaian komputerisasi pun masih sebatas pada pencatatan/pembuatan kutipan/akta. Quality assurance belum pernah dilakukan oleh pihak pemberi layanan, bahkan kotak saran pun sampai saat ini belum disediakan. Itulah sebabnya, kinerja pelayanan di Barito Selatan belum dapat dikatakan sudah baik, namun sebaliknya harus terus ditingkatkan. Dalam hal ini, upaya peningkatan efektivitas pelayanan ditempuh dengan cara penguatan kapasitas SDM melalui pengiriman dalam diklat tertentu, serta pemberian pelayanan di tempat (di rumah masyarakat) khususnya pembuatan akta perkawinan dengan biaya yang lebih murah. Namun secara umum kendala yang ada di Kabupaten Sambas dan Kabupaten Banjar, juga ditemui di Kabupaten Barito Selatan. Disini, kendala yang paling dirasakan selain belum adanya kelembagaan khusus yang menangani pelayanan, adalah terbatasnya sarana prasarana penunjang pelayanan dan jumlah aparatur pelayanan.

Berbeda dengan ketiga daerah diatas, Kota Balikpapan telah menunjukkan kinerja yang sangat tinggi dalam hal pelayanan (khususnya bidang kependudukan). Bahkan sistem pelayanan di Kota Balikpapan ini (termasuk Perda Administrasi Kependudukan) telah diadopsi oleh banyak daerah di Indonesia. Pemkot Balikpapan menerapkan sistem KTP Sementara dan KTP bagi orang miskin. Dalam sistem KTP sementara, seorang pendatang akan diberikan KTP sementara dengan membayar sejumlah uang jaminan. Setelah mendapat pekerjaan (dalam kurun 6 bulan tadi), mereka dapat mengajukan KTP tetap. Namun jika setelah enam bulan tetap tidak mendapat pekerjaan, maka mereka diminta pulang atau dipulangkan secara paksa dengan biaya dari uang yang mereka depositkan kepada Pemkot. Sementara bagi warga miskin, pelayanan KTP diberikan secara gratis.

Dengan cara ini, maka diperoleh banyak manfaat, misalnya jumlah penduduk miskin dapat diketahui, sehingga program bantuan bagi penduduk miskin benar-benar dapat mengena sasaran yang benar-benar berhak. Selain itu, seluruh pemegang KTP WNI tetap (termasuk KTP Pra Sejahtera dan KS-1) diikutsertakan dalam program asuransi jiwa. Dengan menerapkan manajemen kependudukan yang modern ini, beberapa manfaat dapat diraih sekaligus, yaitu: 1) tersedianya data kependudukan yang akurat dan up to date; 2) tidak adanya KTP ganda dan hilangnya percaloan dalam pengurusan KTP; 3) termonitornya arus migrasi (masuk dan keluar) penduduk; 4) berkurangnya keluhan masyarakat terhadap kinerja pelayanan kependudukan; 5) terseleksinya penduduk yang masuk ke Kota Balikpapan secara ketat; serta 6) meningkatnya efektivitas dan efisiensi pencapaian program/kebijakan pada bidang tertentu, misalnya program pengentasan kemiskinan.

Penyelenggaraan pelayanan di Kota Balikpapan khususnya dibidang administrasi kependudukan telah mencirikan pengimplementasian model New Public Management (NPM) khusunya model Public Service Orientation dimana dalam penyelenggaraan pelayanan administrasi kependudukan, masyarakat (customer) dapat memilih jenis pelayanan diluar standar pelayanan minimal, sesuai dengan kebutuhan dan kemampuan finansial. Sebagai konsekuensi dari biaya tinggi yang dikeluarkan, maka customer mendapatkan jaminan pemenuhan waktu yang telah ditetapkan dengan adanya mekanisme sanksi kepada penyelenggara pelayanan apabila tidak dapat memenuhi target waktu yang telah ditetapkan. Dimana penyelenggara layanan harus membayar kompensasi (uang) atas keterlambatan 
dengan menggunakan prinsip "makin lama satuan waktu yang dilanggar, maka makin besar prosentase kompensasi yang harus di bayarkan kepada customer".

\section{Catatan Penutup}

Secara umum pelaksanaan reformasi di bidang pelayanan publik memerlukan komitmen yang kuat dari pimpinan nasional dan seluruh penyelenggara negara baik di pusat maupun daerah, serta tergantung dari sikap mental, tekad, semangat, ketaatan dan disiplin para penyelenggara negara, serta dukungan dan partisipasi masyarakat. Sinergi antar pilar dalam konsep good governance ini merupakan syarat pertama dan utama untuk keberhasilan program-program pemerintah, termasuk dalam penyediaan layanan publik.

Dalam tataran empiris, harus diakui bahwa kinerja pelayanan publik masih sangat rendah atau lemah. Banyaknya pengaduan maupun keluhan yang disampaikan masyarakat baik melalui media massa maupun langsung kepada unit/kantor pelayanan merupakan salah satu indikasi bahwa system dan prosedur pelayanan masih belum berjalan dengan baik. Namun harus diakui pula bahwa juga ada pemerintah daerah yang telah menunjukkan komitmen kuat untuk membangun sistem pelayanan publik yang transparan, efektif, dan akuntabel. Hal ini antara lain ditunjukkan oleh investasi yang mahal untuk membangun teknologi informasi, pembentukan lembaga khusus yang menangani pelayanan, serta pengaturan tentang standarisasi mutu pelayanan pada dimensi waktu, persyaratan, biaya, maupun prosedurnya.

Sayangnya, fenomena secara umum di daerah menunjukkan bahwa aspek kelembagaan pelayanan, standarisasi pelayanan, serta penggunaan teknologi modern tadi belum berjalan sebagaimana yang diharapkan. Sebagai contoh, kelembagaan yang mestinya sudah dapat menjalankan fungsi pelayanan "satu atap" atau "satu pintu”, ternyata hanya berfungsi minimalis sebagai "pusat informasi” pelayanan. Kondisi seperti ini dapat mengurangi tingkat efisiensi penggunaan sumber daya daerah, dan oleh karenanya perlu dicegah sedini mungkin. Sementara dilihat dari aspek teknologi, penggunaan information technology dalam proses pelayanan memang terbukti mampu menciptakan efisiensi sumber daya (input) dan efektivitas kerja yang berujung pada peningkatan kepuasan masyarakat (costumer satisfaction). Namun disisi lain, model pelayanan berbasis teknologi ini juga memiliki kelemahan, khususnya daya jangkaunya yang kurang optimal bagi penduduk pedesaan dan kepulauan. Oleh karena itu, untuk daerah yang dicirikan oleh wilayah yang sangat luas dan sulit terjangkau, maka pelimpahan sebagian fungsi pemberian pelayanan dan/atau periijinan kepada kecamatan, justru merupakan opsi yang tepat. Adapun mengenai standarisasi prosedur, pola pikir bahwa semakin cepat pelayanan semakin baik, nampaknya perlu diubah. Contoh Balikpapan yang memberikan pilihan alternatif proses pelayanan, justru terbukti memberikan dampak yang menguntungkan secara timbal balik, baik bagi pemerintah daerah (service provider) maupun bagi masyarakat sendiri (costumer).

Disamping itu, untuk memberikan kepastian pelayanan kepada masyarakat, perlu dikembangkan pendekatan pelayanan publik dalam bentuk Kontrak Pelayanan (KP) sebagai 
salah satu praktek New Public Management (NPM). Dimanana KP ini akan menjadi acuan (kesepakatan) antara pengguna layanan dan pemberi layanan terhadap prosedur pelayanan, waktu dan biaya pelayanan, sehingga fungsi kontrol dari publik akan berjalan dengan lebih baik. Disamping juga diperlukan lembaga khusus yang diberikan kewenangan untuk melakukan fungsi pengawasan dan penilaian kinerja terhadap penyelenggaraan pelayanan di tingkat daerah.

\section{Referensi}

Azis, Abdul dan David D. Arnold, 2003, Desentralisasi Pemerintahan Pengalaman NegaraNegara Asia, Pondok Edukasi.

Dwiyanto, Agus dan Bevaola Kusumasari, 2003, Reformasi Pelayanan Publik: apa yang harus dilakukan? dalam Policy Brief No.11/PB/2003.Yogyakarta: Pusat Studi Kependudukan dan Kebijakan, Universitas Gadjah Mada.

Ferlie, Ewan, et al, 1997, The New Public Management in Action, Oxford University Press, New York, dalam Reformasi Pelayanan Publik: apa yang harus dilakukan? dalam Policy Brief No.11/PB/2003.Yogyakarta: Pusat Studi Kependudukan dan Kebijakan, Universitas Gadjah Mada.

Henry, Nicholas, 1988, Administrasi Negara dan Masalah-Masalah Kenegaraan, Terjemahan Luciana D. Lontoh, Rajawali, Jakarta.

Hoesein, Bhenyamin, 2000, Hubungan Penyelenggaraan Pemerintah Pusat Dengan Pemerintah Daerah, Jurnal Bisnis dan Birokrasi No. 1/Vol.1/Juli/2000.

Hughes, Owen E, 1994, Public Management and Administration, St. Martin's Press, New York, dalam Reformasi Pelayanan Publik: Apa yang harus dilakukan? dalam Policy Brief No.11/PB/2003.Yogyakarta: Pusat Studi Kependudukan dan Kebijakan, Universitas Gadjah Mada.

Kantor Kependudukan dan Catatan Sipil Balikpapan, 2004, Manajemen Kependudukan Kota Balikpapan, Balikpapan.

Kompas, 2005, RUU Pelayanan Publik: Penting dan Rumit Demi Kupuasan Rakyat, edisi 16 Desember.

Kusumari, Bevaora, 2005, Kontrak Pelayanan dalam Reformasi Pelayanan Publik di Indonesia, dalam Birokrasi Publik: Dalam Sistem Politik Semi-Parlementer, Gava Media, Yogyakarta

Pemkab Sambas, 2004, Information for Investment in Sambas Regency: Prospek, Potensi, dan Peluang Investasi Kabupaten Sambas.

Purwanto, Erwan Agus dan Wahyudi Kumorotomo, et.al. 2005, Birokrasi Publik: Dalam Sistem Politik Semi-Parlementer, Gava Media, Yogyakarta. 
Sarundajang, S.H, 2000, Arus Balik Kekuasaan Pusat ke Daerah, Jakarta: Pustaka Sinar Harapan.

UNDP, 1996, Local governance, Report of the United Nations Global Forum on Innovative Policies and Practices in Local Governance, Gothenburg Sweden.

Utomo, Tri Widodo W., et.al.2005. "Peningkatan Efektivitas Penyelenggaraan Pemda Otonom Kabupaten/Kota di Kalimantan”, Samarinda: PKP2A III LAN. 